\title{
Ketahanan Empat Kultivar Ubi Kayu Terhadap Tetranychus kanzawai Kishida (Acari: Tetranychidae)
}

\section{(The Resistance of Four Cassava Cultivars to Tetranychus kanzawai Kishida (Acari: Tetranychidae))}

\author{
Sugeng Santoso ${ }^{1 *}$ dan Widi Astuti ${ }^{1}$ \\ ${ }^{1}$ Departemen Proteksi Tanaman, Faperta IPB \\ *Email korespondensi: ssantoso@apps.ipb.ac.id
}

Diterima 23 Juli 2019 / Disetujui 03 September 2019

\begin{abstract}
Red spider mite (Tetranychus kanzawai Kishida) is one of the most important pests of cassava. The damage caused by this mite may reduce the yield up to 95\%. The tolerance of cultivar is suggested as one of the factors affected amount of yield loss. Resistant cassava cultivars may be used as an alternative method to control the mite. This research evaluated the resistance of four cassava cultivars against red spider mite. Research was conducted in the greenhouse to observe the development of damages caused by the mite on Manggu, Jimbul, Roti, and Mentega cultivars. Observation of biology and lifecycle was conducted in the laboratory. Every cultivar showed different resistance against T. kanzawai. Manggu cultivar showed the lowest damage, while Mentega cultivar showed the highest. On Manggu cultivar, T. kanzawai had the longest life cycle and lowest fecundity.
\end{abstract}

Keywords: cultivar, development of damage, fecundity, life cycle, resistance, Tetranychus kanzawai.

\section{ABSTRAK}

Tungau merah (Tetranychus kanzawai Kishida) merupakan hama penting pada ubi kayu. Hama tersebut menyebabkan kehilangan hasil sebesar 95\%. Penggunaan kultivar merupakan faktor yang mempengaruhi kehilangan hasil. Kultivar ubi kayu yang tahan terhadap tungau merah dapat digunakan sebagai salah satu alternatif pengendalian. Penelitian ini bertujuan mengetahui ketahanan kultivar Manggu, Roti, Jimbul, dan Mentega terhadap T. kanzawai. Penelitian di rumah kaca dilakukan untuk mengetahui intensitas kerusakan pada kultivar Mannggu, Roti, Mentega, dan Jimbul. Pengamatan biologi T. kanzawai dilakukan di laboratorium. Hasil pengamatan menunjukkan bahwa setiap kultivar menunjukkan ketahanan terhadap T. kanzawai yang berbeda-beda. Kultivar Manggu menunjukkan intensitas kerusakan paling rendah dan kultivar Mentega menunjukkan intensitas kerusakan paling tinggi. Pada kultivar Manggu T. kanzawai menunjukkan waktu perkembangan yang lebih panjang dan memiliki keperidian yang lebih rendah.

Kata Kunci: intensitas kerusakan, kultivar, keperidian, ketahanan, siklus hidup, Tetranychus kanzawai

\section{PENDAHULUAN}

Ubi kayu merupakan salah satu komoditas pangan yang sangat penting di Indonesia. Menurut BPS (2013) produksi ubi kayu pada tahun 2012 mencapai 22 juta ton dengan luas panen 1.1.ha dan produktivitas 16.2 ton/ha. Produksi ini menurun 5.68\% dibandingkan tahun 2011. Penurunan produktivitas ubi kayu dapat disebabkan oleh beberapa faktor, diantaranya serangan Organisme Pengganggu Tanaman (OPT).

Tungau merah Tetranychus kanzawai Kishida merupakan salah satu hama penting pada pertanaman ubi kayu. Gejala serangannya berupa nekrosis pada permukaan daun yang dimulai dari sekitar pertulangan daun. Serangan tersebut akan meluas ke seluruh permukaan daun dan pada serangan tinggi mengakibatkan terjadinya kerontokan daun dan menimbulkan kematian. Menurut Indiati (2012), serangan tungau merah berpengaruh terhadap ukuran dan kualitas umbi. Penurunan hasil yang disebabkan oleh serangan hama tersebut dapat mencapai 20\%-53\%, hal ini dipengaruhi oleh umur tanaman dan lamanya waktu serangan, dan pada tingkat serangan tinggi kehilangan hasil dapat mencapai 95\% (Prihandana et al. 2007). Upaya pengendalian yang komprehensif diperlukan untuk menurunkan potensi kehilangan hasil akibat serangan $T$. kanzawai.

Pengendalian terhadap tungau merah dapat dilakukan dengan berbagai cara baik secara kimia, biologi maupun kultur teknis. Di Indonesia pengendalian terhadap tungau merah pada ubi kayu belum dilakukan secara optimal oleh petani. Hal ini berkaitan erat dengan nilai ekonomi ubi kayu yang relatif rendah, sehingga tidak sebanding dengan biaya pengendalian yang harus dikeluarkan oleh petani, terutama harga pestisida dirasa masih relatif mahal. Dengan demikian, diperlukan teknik pengendalian yang praktis, stabil, dan ekonomis. 
Penggunaan kultivar tahan merupakan salah satu cara pengendalian yang murah, mudah, dan tidak mencemari lingkungan. Departemen Pertanian telah melepas sepuluh kultivar unggul ubi kayu. Sebanyak enam kultivar dimodivikasi tahan terhadap serangan hama tungau merah seperti Adira 1, Adira 2, Malang 1, Malang 4, Malang 6, dan Darul Hidayah (Sundari 2010). Penggunaan kultivar ubi kayu yang tahan mampu menurunkan intensitas kerusakan yang disebabkan oleh serangan tungau, menghambat reproduksi tungau, sehingga penggunaan kultivar tahan diharapkan dapat menekan kehilangan hasil.

Penelitian ini dilakukan terhadap beberapa kultivar ubi kayu lokal yang banyak dibudidayakan oleh petani di daerah Bogor. Kultivar lokal tersebut diantaranya Manggu, Roti, Mentega dan Jimbul. Ketahanan keempat kultivar tersebut terhadap tungau merah belum banyak diketahui. Oleh karena itu penelitian ini bertujuan mengetahui ketahanan keempat kultivar ubi kayu tersebut terhadap serangan T. kanzawai, selain itu damati pula siklus hidup $T$. kanzawai pada keempat kultivar mengetahui pengaruh kultivar terhadap perkembangan siklus hidup T. kanzawai, sehingga penelitian ini diharapkan dapat menjadi acuan sebagai salah satu alternatif pengendalian.

\section{BAHAN DAN METODE}

\section{Penanaman Ubi Kayu}

Batang ubi kayu dari masing-masing kultivar dipotong berukuran $20 \mathrm{~cm}$, kemudian ditanam pada polibag berukuran $40 \mathrm{~cm}$ x $35 \mathrm{~cm}$ dengan menggunakan media tanam berupa tanah dan kompos sebanyak $4 \mathrm{~kg}$. Masingmasing kultivar ditanam sebanyak 20 ulangan, sehingga jumlah tanaman yang diamati sebanyak 80 tanaman.

\section{Infestasi T. Kanzawai}

Tanaman ubi kayu yang diinfestasi T. kanzawai adalah tanaman yang sudah berumur 2 minggu setelah tanam (MST). Kemudian, lima imago betina diinfestasikan pada permukaan bawah daun dengan menggunakan kuas. Daun yang diinfestasi adalah daun yang berada di bagian tengah kemudian daun yang telah diinfestasi diberi label.

\section{Peubah Pengamatan Intensitas Kerusakan T. kanzawai pada Tanaman}

Pengamatan dilakukan 1 minggu setelah infestasi (pada saat tanaman berumur $3 \mathrm{MST}$ ). Intensitas kerusakan dihitung dengan menggunakan rumus:

$$
\mathrm{I}=\frac{\sum \mathrm{nix} \text { vi }}{\mathrm{NxV}} \times 100 \%
$$

$\mathrm{I}=$ intensitas serangan, $\mathrm{ni}=$ jumlah daun dalam setiap kategori skor, vi = kategori skor (0 sampai 5), $\mathrm{N}=$ jumlah daun dalam satu tanamam, $\mathrm{V}=$ nilai skor tetinggi (dalam hal ini 5). Skoring intensitas kerusakan dilakukan dengan pengamatan berdasarkan metode Indiati (2012) yang dimodifikasi (Tabel 1).

\section{Biologi T. Kanzawai}

T. kanzawai yang digunakan berasal dari ubi kayu yang ditanam di laboratorium. Percobaan dilakukan di cawan petri berdiameter $6 \mathrm{~cm}$, di dalamnya diletakkan busa plastik berdiameter $5 \mathrm{~cm}$. Di atas busa diletakkan kapas berukuran $3 \mathrm{~cm}$ x $3 \mathrm{~cm}$. Pada permukaan kapas diletakkan daun ubi kayu berukuran $2 \mathrm{~cm} \times 2 \mathrm{~cm}$. Busa dan kapas dijenuhi oleh air, dengan tujuan menjaga kelembaban dan kesegaran daun serta mencegah tungau keluar dari tempat percobaan. Sebanyak 50 imago betina T. kanzawai dari masing-masing kultivar di pelihara pada daun ubi kayu yang sama dengan kultivar asal T. kanzawai, kemudian dibiarkan selama 2 jam agar bertelur. Setelah imago meletakkan telur, telur yang digunakan dalam setiap arena percobaan adalah satu butir telur (50 butir telur dari tiap kultivar ubi kayu). Setelah itu, telur diamati setiap enam jam sampai menetas dan menjadi imago. Lama perkembangan dari setiap stadia dicatat. Imago yang terbentuk dihitung dan dilihat nisbah kelaminya. Setelah menjadi imago pengamatan dilakukan setiap hari untuk mengetahui masa praoviposisi, oviposisi, pascaoviposisi, keperidian, serta lama hidup imago.

\section{Rancangan Percobaan dan Analisis Data}

Rancangan percobaan yang digunakan yaitu rancangan acak lengkap (RAL) dengan kultivar sebagai perlakuan dan diulang sebanyak 20 ulangan. Intensitas kerusakan dan biologi diolah dengan menggunakan Microsoft Office Excel 2007. Data dianalisis dengan ANOVA menggunakan program Statistical Analysis System (SAS), perlakuan yang berpengaruh diuji lanjut dengan menggunakan uji Duncan pada taraf nyata $5 \%$.

\section{HASIL DAN PEMBAHASAN}

\section{Gejala Kerusakan pada Tanaman}

Gejala serangan Tungau merah pada ubi kayu mulai tampak pada saat tanaman berumur 3 MST. Pada bagian permukaan bawah daun terlihat bintink-bintik kuning di sekitar tulang daun. Serangan tersebut menyebabkan daun mengalami bercak nekrosis dan bercak berubah menjadi berwarna coklat. Serangan yang parah menyebabkan bercak nekrosis meluas ke seluruh permukaan daun, dan sampai ke pucuk daun. Pucuk daun yang terserang mengalami perubahan bentuk menjadi mengerut dan kerdil serta pada permukaan daun terdapat benang-benang putih dari $T$. kanzawai dan lama-kelamaan daun menjadi kering dan rontok. Menurut Belloti et al.(1990), serangan tungau merah pada ubi kayu diawali dari daun-daun yang berada dibagian bawah kemudian meluas menyerang daun-daun yang berada di bagian atas, sehingga bagian pucuk mengalami serangan paling akhir. 
Tabel 1 Skoring intensitas kerusakan ubi kayu berdasarkan luas nekrosis

\begin{tabular}{ccl}
\hline Skor & Besarnya kerusakan $(\%)$ & \multicolumn{1}{c}{ Keterangan } \\
\hline 0 & 0 & $\begin{array}{l}\text { Daun sehat (tidak ada bercak) } \\
\text { Ada awal bercak kekuningan (sekitar 10\%) pada beberapa daun bawah dan } \\
\text { atau daun tengah. }\end{array}$ \\
2 & $10<\mathrm{x} \leq 20$ & $\begin{array}{l}\text { Bercak kekuningan agak banyak (11-20\%) pada daun bawah dan tengah. } \\
\text { Kerusakan yang jelas, banyak bercak kuning (21-50\%), sedikit daerah } \\
\text { mengalami nekrotik }(<20 \%), \text { khususnya daun bawah dan tengah agak } \\
\text { mengerut, sejumlah menjadi kuning dan rontok. }\end{array}$ \\
& $50<\mathrm{x} \leq 50$ & $\begin{array}{l}\text { Kerusakan parah (51-75\%) pada daun bagian bawah dan tengah, populasi } \\
\text { tungau melimpah dan dijumpai benang-benang putih seperti jaring laba-laba. } \\
\text { Kerontokan daun total; pucuk tanaman mengecil, benang putih semakin } \\
\text { banyak, dan kematian tanaman. }\end{array}$ \\
\hline 5 & $\mathrm{x}>75$ &
\end{tabular}

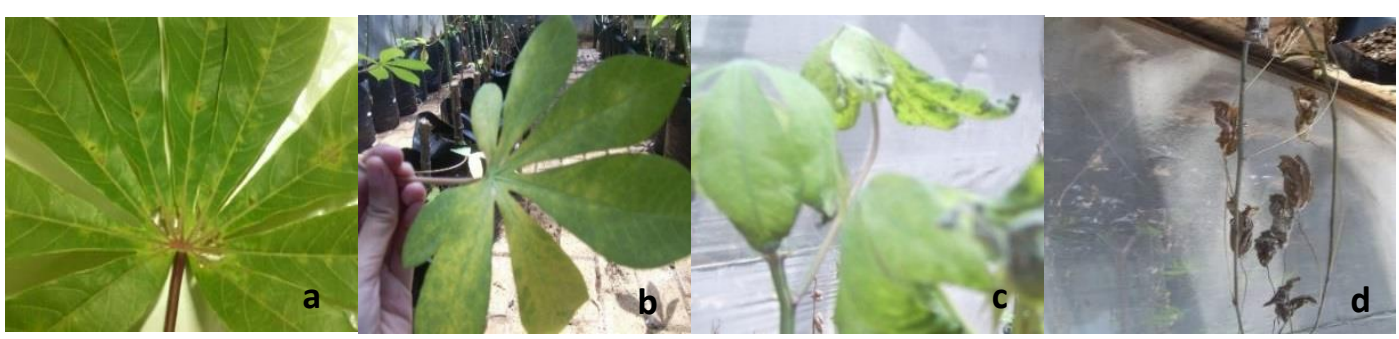

Gambar 1 Gejala serangan tungau merah T. kanzawai pada ubi kayu: (a) gejala awal serangan, (b) bercak nekrotik meluas ke permukaan daun, (c) pucuk daun mengalami perubahan bentuk, (d) daun mengering dan rontok.

Tabel 2 Intensitas kerusakan oleh T. kanzawai pada keempat varietas ubi kayu

\begin{tabular}{ccccc}
\hline \multirow{2}{*}{ Waktu pengamatan (MST) } & \multicolumn{4}{c}{ Intensitas kerusakan pada kultivar (\%) ${ }^{\mathrm{a}}$} \\
\cline { 2 - 5 } & Manggu & Roti & Mentega & $7.945 \mathrm{a}$ \\
4 & $4.625 \mathrm{~b}$ & $6.400 \mathrm{ab}$ & $9.200 \mathrm{a}$ & $14.275 \mathrm{~b}$ \\
5 & $14.270 \mathrm{~b}$ & $27.015 \mathrm{a}$ & $28.965 \mathrm{a}$ & $35.060 \mathrm{a}$ \\
6 & $14.950 \mathrm{~b}$ & $38.395 \mathrm{a}$ & $35.330 \mathrm{a}$ & $61.220 \mathrm{~b}$ \\
7 & $52.710 \mathrm{~b}$ & $79.257 \mathrm{a}$ & $79.045 \mathrm{a}$ & $82.600 \mathrm{ab}$ \\
8 & $74.405 \mathrm{~b}$ & $81.655 \mathrm{ab}$ & $95.170 \mathrm{a}$ & $55.150 \mathrm{ab}$ \\
9 & $34.980 \mathrm{~b}$ & $36.530 \mathrm{~b}$ & $77.500 \mathrm{a}$ & $52.360 \mathrm{~b}$ \\
10 & $28.260 \mathrm{c}$ & $50.140 \mathrm{~b}$ & $75.620 \mathrm{a}$ & $64.200 \mathrm{~b}$ \\
\hline
\end{tabular}

${ }^{a}$ rataan pada baris yang sama diikuti oleh huruf yang sama tidak berbeda nyata (uji selang ganda Duncan. $\alpha=0.05$ ). MST= Minggu Setelah Tanam.

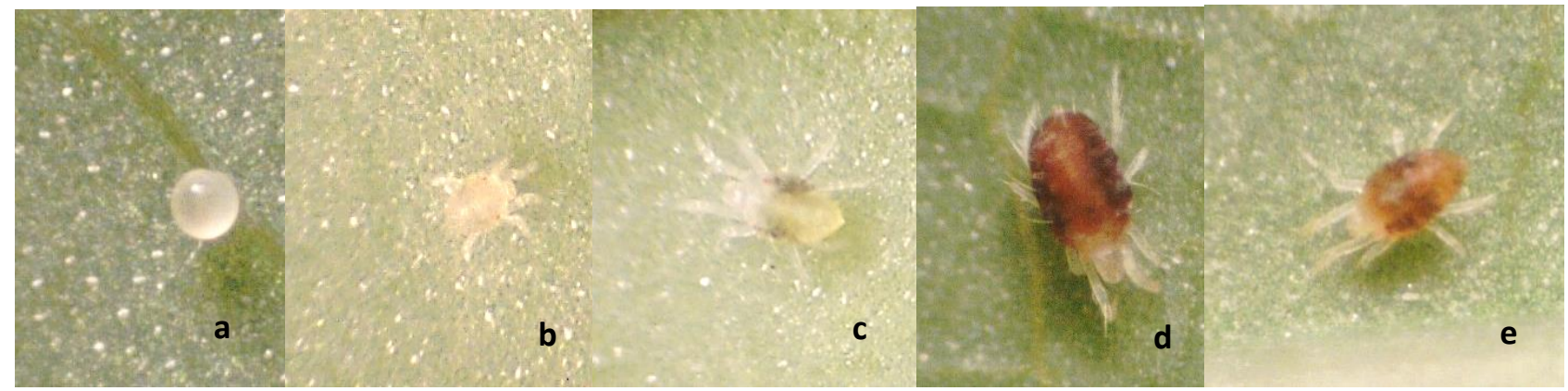

Gambar 2 . Fase perkembangan Tetranychus kanzawai: (a) telur (b) larva (c) nimfa (d) imago betina (e) imago jantan 
Tabel 3 Lama perkembangan pradewasa Tetranychus kanzawai pada kultivar ubi kayu

\begin{tabular}{|c|c|c|c|c|c|c|c|c|}
\hline \multirow{3}{*}{ Kultivar } & \multicolumn{6}{|c|}{ Lama perkembangan stadia (hari) $^{\mathrm{a}}$} & \multirow{2}{*}{\multicolumn{2}{|c|}{ Total }} \\
\hline & \multicolumn{2}{|c|}{ Telur } & \multicolumn{2}{|c|}{ Larva } & \multicolumn{2}{|c|}{ Nimfa } & & \\
\hline & Jantan & Betina & Jantan & Betina & Jantan & Betina & Jantan & Betina \\
\hline Manggu & $3.05 \mathrm{a}$ & $3.55 \mathrm{a}$ & $2.05 \mathrm{a}$ & $2.65 \mathrm{a}$ & $2.47 \mathrm{a}$ & $2.60 \mathrm{a}$ & $7.35 \mathrm{a}$ & $8.88 \mathrm{a}$ \\
\hline Roti & $2.47 \mathrm{a}$ & $2.95 b$ & $2.38 \mathrm{a}$ & $2.29 b$ & $2.29 \mathrm{ab}$ & $2.44 \mathrm{ab}$ & $7.01 \mathrm{a}$ & $7.76 b$ \\
\hline Mentega & $2.28 \mathrm{a}$ & $2.88 \mathrm{~b}$ & $2.51 \mathrm{a}$ & $2.12 b$ & $1.96 \mathrm{~b}$ & $2.21 \mathrm{~b}$ & $6.75 b$ & $7.08 \mathrm{c}$ \\
\hline Jimbul & $2.47 \mathrm{a}$ & $2.86 \mathrm{~b}$ & $2.03 \mathrm{a}$ & $2.22 b$ & $2.27 \mathrm{a}$ & $2.20 \mathrm{~b}$ & $6.78 \mathrm{~b}$ & $7.84 \mathrm{~b}$ \\
\hline
\end{tabular}

${ }^{\mathrm{a}}$ Rataan selajur yang diikuti oleh huruf yang sama tidak berbeda nyata (uji selang ganda Duncan. $\alpha=0.05$ ).

Tabel 4 Perkembangan Imago Tetranychus kanzawai pada kultivar ubi kayu

\begin{tabular}{|c|c|c|c|c|}
\hline \multirow{2}{*}{ Parameter } & \multicolumn{4}{|c|}{ Varietas } \\
\hline & Manggu & Roti & Mentega & Jimbul \\
\hline Masa Praoviposisi (hari) & $1.300 \mathrm{a}$ & $0.800 \mathrm{bc}$ & $1.045 \mathrm{ab}$ & $0.800 \mathrm{c}$ \\
\hline Oviposisi (hari) & $5.150 \mathrm{c}$ & $6.448 b$ & $7.540 \mathrm{a}$ & $7.933 \mathrm{a}$ \\
\hline Pascaoviposisi & $2.225 \mathrm{a}$ & $0.931 b$ & $0.459 \mathrm{c}$ & $0.567 b c$ \\
\hline Kepiridian & $15.825 \mathrm{~b}$ & $28.448 \mathrm{a}$ & $33.270 \mathrm{a}$ & $34.000 \mathrm{a}$ \\
\hline \multicolumn{5}{|l|}{ Lama hidup imago (hari) } \\
\hline Jantan & $6.950 \mathrm{a}$ & $6.769 \mathrm{a}$ & $5.952 b$ & $6.975 \mathrm{a}$ \\
\hline Betina & $10.693 a$ & $8.379 b$ & $8.283 b$ & $9.035 b$ \\
\hline $\begin{array}{l}\text { Nisbah kelamin } \\
\text { (jantan dan betina) }\end{array}$ & 0.4 & 0.72 & 0.35 & 0.66 \\
\hline
\end{tabular}

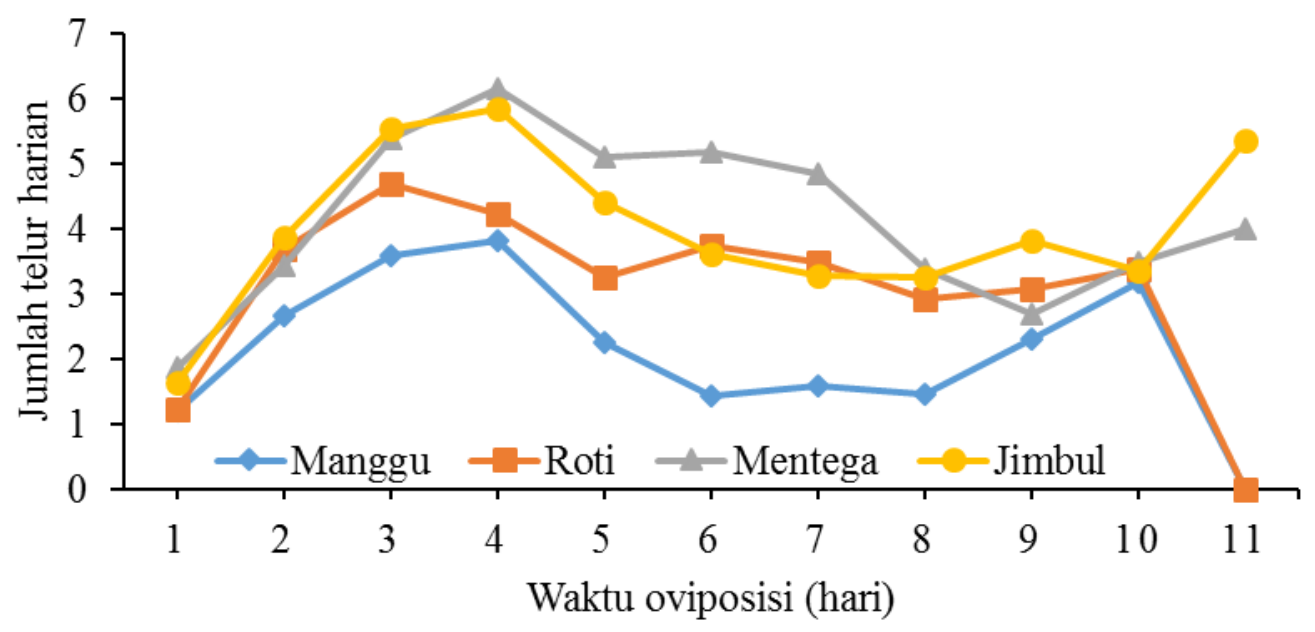

Gambar 3 Jumlah telur harian Tetranychus kanzawai pada kultivar ubi kayu

\section{Intensitas Kerusakan Tanaman Ubi Kayu}

Intensitas kerusakan pada saat tanaman berumur 3 MST menunjukkan tingkat kerusakan relatif rendah yaitu kurang dari $10 \%$ pada keempat kultivar. Intensitas kerusakan meningkat pada saat tanaman berumur 5 MST. Intensitas kerusakan pada Roti, Mentega, dan Jimbul lebih dari 35\%, sedangkan Manggu menunjukkan intensitas kerusakan yang lebih rendah yaitu $14.95 \%$. Kerusakan maksimum terjadi pada saat tanaman berumur 7 MST yaitu daun tanaman mengalami rontok total dan tanaman mengering, serta pada kultivar Mentega hampir 90\% tanaman mati, sehingga intensitas kerusakan yang terjadi pada kultivar tersebut lebih tinggi dibandingkan dengan kultivar lainya, dengan intensitas kerusakan pada kultivar tersebut mencapai $95 \%$. Kultivar Manggu pada saat serangan tinggi memiliki jumlah daun hijau yang lebih banyak dibandingkan kultivar lainya. Hal ini menyebabakan intensitas kerusakan yang terjadi pada Manggu lebih rendah dibandingkan dengan kultivar lainya (Tabel 2). Nukenin et al. (1999) menyatakan bahwa tanaman ubi kayu yang toleran terhadap kekeringan memiliki kemungkinan tahan terhadap serangan tungau 
merah dan secara genetik memiliki kemampuan mempertahankan jumlah daun hijau yang banyak.

Setelah mengalami kerontokan, beberapa tanaman mengalami pertumbuhan tunas baru. Kemunculan tunas baru terjadi pada saat tanaman berumur 8 MST. Kerusakan yang terjadi pada tunas baru relatif rendah, sehingga Intensitas kerusakan yang terjadi pada 8 MST mengalami penurunan. Menurut Gultom (2010), kerusakan dan populasi tungau merah T. kanzawai pada daun tua lebih tinggi dibandingkan dengan daun muda. Daun muda pada tanaman ubi kayu memiki trikoma yang lebih banyak, namaun pada saat daun tanaman berkembang trikoma tersebut hilang (Indiati 2012). Trikoma pada daun dapat menghambat serangga untuk meletakan telur.Setelah daun tanaman berkembang, bercak nekrosis meluas pada permukaan daun, sehingga intensitas kerusakan meningkat kembali, seperti yang terjadi pada saat tanaman berumur 9 dan 10 MST (Tabel 2). Namun, pada kultivar Manggu intensitas kerusakan yang terjadi setelah daun berkembang menunjukkan intensitas kerusakan yang lebih rendah dibandingkan dengan kultivar lainya dengan intensitas kerusakan di bawah $40 \%$ (Tabel 2). Menurut Carlson et al. (1979), tanaman dapat dikatakan toleran terhadap tungau, ketika menunjukkan tingkat kerusakan yang rendah.

Selama waktu pengamatan kultivar Manggu menunjukkan intensitas kerusakan lebih rendah dibandingkan kultivar lainya, sedangkan perkembangan intensitas kerusakan lebih tinggi terjadi pada kultivar Mentega. Menurut Indiati (2012), pada tingkat serangan tinggi, semua kultivar pada umumnya akan menunjukan intensitas kerusakan yang tinggi, perbedaan ketahanan pada masing-masing kultivar terletak pada waktu munculnya gejala serangan awal sampai terbentuk serangan yang parah, adapun munculnya gejala serangan pada kultivar tahan lebih lama dibandingkan dengan kultivar yang tidak tahan.

\section{Perkembangan Pradewasa T. Kanzawai}

Intensitas kerusakan pada ubi kayu dapat dipengaruhi oleh siklus hidup dan reproduksi dari T. kanzawai. Siklus hidup T. kanzawai meliputi fase telur, larva, nimfa dan imago (Gambar 2). Telur T. kanzawai berwarna putih bening, dan menjadi berwarna kuning tua saat akan menetas. Telur berbentuk bulat, dan diletakan satu persatu oleh imago betina dibawah permukaan daun, telur berukuran $0.05 \mathrm{~cm}$. Larva memiliki tiga pasang tungkai, dan berukuran $0.2 \mathrm{~cm}$. Larva berwarna kuning muda dan lama-lama berubah menjadi kunig kehijauan. Menurut Decianto et al. (1991), larva dapat berubah warna menjadi kehijauan disebabkan karena larva telah mampu menghisap cairan tanaman. Nimfa memiliki empat pasang tungkai, berwarna hijau kekuningan pada bagian tubuhnya terdapat bercak berwarna hitam, dan berukuran $0.35 \mathrm{~cm}$. Imago betina memiliki ukuran dua sampai tiga kali lebih besar dari imago jantan (Takafuji et al. 1989). Imago betina berwarna merah, berbentuk lebih bulat, sedangkan imago jantan memiliki ujung abdomen kerucut.

Total waktu perkembangan pradewasa dimulai sejak telur diletakan sampai terbentuknya imago. Lama perkembangan stadia telur, larva, dan nimfa betina pada kultivar Manggu menunjukkan waktu perkembangan yang lebih lama dibandingkan dengan kultivar lainya, sedangakan lama perkembangan telur dan larva jantan pada masingmasing kultivar menunjukkan lama perkembangan yang tidak berbeda nyata (Tabel 3). Lama perkembangan nimfa jantan pada masing-masing kultivar menunjukan waktu yang berbeda. Adapun lama perkembangan nimfa jantan pada kultivar Manggu dan Jimbul lebih lama dibandingkan dengan kultivar Roti dan Mentega (Tabel 3).

Total perkembangan pradewasa betina lebih lama dibandingkan dengan waktu perkembangan pradewasa jantan (Tabel 3). Hal ini menunjukan imago jantan lebih cepat terbentuk dari pada imago betina. Imago jantan kerap kali berada disamping betina untuk mendampingi betina ketika masih dalam fase teliokrisalis, proses pendampingan ini disebut dengan precopulatory cuarding (Gultom 2010). Ketika imago betina terbentuk maka jantan akan segera menyodorkan alat kopulasinya kepada betina. Pembentukan betina yang lebih panjang akan memperlambat terjadinya kopulasi. Waktu kopulasi yang terhambat mengakibatkan perkembangan regenersi $T$. kanzawai akan lama karena waktu yang dibutuhkan untuk menyelesaikan siklus hidup menjadi semakin lama.

Jenis kultivar ubi kayu memberikan pengaruh terhadap lama perkembangan pradewasa. Kultivar Manggu menunjukan total perkembangan pradewasa yang lebih lama dibandingkan dengan kultivar lainya baik pada pradewasa betina maupun pradewasa jantan secara berturut-turut lama perkembangan yaitu sekitar 8.8 hari dan 7.5 hari. Menurut Khoiri (2005) lama perkembangan pradewasa tungau merah pada ubi kayu pahit yaitu 7.80 hari dan pada ubi kayu manis 7.70 hari.

\section{Perkembangan Imago T. Kanzawai}

Jumlah imago betina yang terbentuk pada masingmasing kultivar lebih banyak dibandingkan dengan jantan. Perkembangan tungau merah terjadi secara partenogenesis. Menurut Takafuji et al. (1989), Telur yang dibuahi akan menjadi betina, dan yang tidak dibuahi akan menjadi jantan, sehingga nisbah kelamin betina lebih besar dibandingkan dengan jantan. Nisbah kelamin betina tungau merah pada suatu populasi dapat mencapai $67 \%$ dari jantan (Zhang 2003). Jumlah jantan pada kultivar mentega lebih sedikit dibandingkan kultivar lainya yaitu dengan nisbah kelamin jantan terhadap betina sebesar 0.35 (Tabel 4). Jumlah imago betina yang lebih banyak akan menghasilkan keturunan betina yang lebih banyak, dan dapat meningkatkan populasi tungau merah sehingga akan meningkatkan intensitas kerusakan.

Lama hidup imago jantan pada masing-masing kultivar menunjukkan waktu perkembangan yang lebih singkat dibandingkan dengan betina. Lama hidup imago jantan pada Mentega lebih singkat dibandingkan dengan kutivar lainya (Tabel 4). Sedangkan, lama hidup imago betina pada kultivar Manggu lebih panjang dibandingkan kultivar lainya. Dengan lama hidup imago yang semakin cepat memungkinkan terjadinya regenerasi $T$. kanzawai menjadi lebih cepat. Menurut Belloti et al. (1986), kultivar 
ubi kayu memiliki pengaruh terhadap waktu perkembangan tungau merah, dimana perkembangan tungau merah pada kultivar tahan menunjukan waktu perkembangan yang lebih lambat dibandingkan dengan kultivar tidak tahan. Lama hidup imago betina meliputi masa praoviposisi, oviposisi, dan pascaoviposisi.

${ }^{a}$ Rataan selajur yang diikuti oleh huruf yang sama tidak berbeda nyata (uji selang ganda Duncan. $\alpha=0.05$ ).

Masa praoviposisi merupakan masa sebelum imago meletakkan telur pertama. Umumnya masa praoviposisi terjadi dalam waktu yang singkat. Masa praoviposisi pada masing-masing kultivar menunjukan waktu yang berbedabeda, adapun masa praoviposisi pada kultivar Mentega lebih cepat, sedangkan pada Manggu masa praoviposisi terjadi lebih lambat (Tabel 3). Masa praoviposisi yang lebih lama mempengaruhi waktu untuk pelatakan telur pertama menjadi lebih lambat.

Masa imago betina mulai meletakan telur disebut dengan masa oviposisi. Pada kultivar Mentega dan Jimbul, $T$. kanzawai memiliki masa oviposisi lebih lama dibadingkan dengan kultivar lainya adapun waktu oviposisi pada ke dua kultivar tersebut tidak berbeda nyata yaitu biperkisar antara 7.5-7.9 hari (Tabel 4). Menurut Zhang (2003), masa oviposisi tungau merah berlangsung selama sekitar 10 hari. Semakin lama masa oviposisi akan berpengaruh terhadap tingkat keperidian yang semakin tinggi (Gultom 2010).

Imago betina tungau merah pada ubi kayu pahit mampu meletakkan telur hingga 54.70 butir/betina (Khoiri 2005). Skorupska (2004) menyatakan bahwa kondisi terbaik untuk perkembangan tungau ditentukan oleh nilai reproduksi. Hasil peneltian menunjukan bahwa Rata-rata keperidian imago T. kanzawai pada kultivar Jimbul, Mentega, dan Roti tidak berbeda nyata dengan jumlah telur yaitu 34, 33, 28 telur/betina. Sedangakan keperidian imago betina pada kultivar Manggu lebih rendah dibandingkan kultivar lainya yaitu 15.8 telur/betina (Tabel 4 ).

Kultivar ubi kayu memberikan pengaruh terhadap jumlah peletakan telur harian (Gambar 2). Menurut Easterbrook et al. (1994), Keperidian (peletakan telur harian) pada tungau dapat digunakan untuk mengukur ketahanan tanaman inang terhadap tungau, tungau merah pada kultivar tahan menunjukkan jumlah peletakan telur harian yang rendah. Imago betina T. kanzawai pada kultivar Manggu meletakan jumlah telur harian yang lebih sedikit dibandingkan kultivar lainya. Dengan jumlah telur harian yang diletakan sedikit maka akan menurunkan jumlah $T$. kanzawai pada generasi berikutnya, sehingga intensitas kerusakan pada ubi kayu akan menurun. Pada awal peneluran, telur yang diletakan imago betina jumlahnya sedikit, dan pada hari berikutnya jumlah telur meningkat, kemudian mengalami penurunan hingga akhirnya imago tidak meletakan telur yang disebut dengan masa pascaoviposisi. Betina pada masa pascaoviposisi cenderung diam, tidak aktif bergerak, dan akan mati.

\section{KESIMPULAN}

Kultivar Manggu dapat digunakan sebagai alternatif pengendalian. Intensitas yang terjadi pada kultivar tersebut lebih rendah dibandingkan kultivar lainnya. Perkembangan T. kanzawai pada kultivar Manggu lebih lambat dan memiliki tingkat keperidian yang lebih rendah dibandingkan kultivar lainya. Hal ini menunjukkan bahwa kultivar Manggu lebih tahan terhadap serangan $T$. kanzawai dibandingkan kultivar lainnya.

\section{DAFTAR PUSTAKA}

[BPS] Badan Pusat Statistik. 2013. Produksi Ubi kayu. Jakarta (ID): BPS.

Belloti, A.C., J.A. Reyyes, dan J.M. Guerero. 1986. Cassava Mite and Their Control. Colombia (CO): Centro Internacional de Agricultura Tropical.

Bellotti, A.C. 1990. A review of control strategies for four important cassava pests in the Americas. In S.K. Hahn, and F.E. Caveness (Eds). Integrated Pest Management for Tropical Root and Tuber Crops. hlm:58-65.

Carlson, E.C., B.H. Beard, R. Tarailo, dan R.L. Witl. 1979. Testing soybeans for resistence to spider mites. California Agriculture. hlm:9-11.

Deciyanto, S, I.M. Trisawa dan R.R. Adriani. 1991. Studi beberapa inang hama tungau (Tetranychus sp) asal tanaman Mentha sp. Penel Tan Industri. 17(2): 48-55.

Easterbrook, M.A. dan D.W. Simpson. 1994. Strawberry: host plant resistance to two-spotted spider mite. Relevance to Growers and Practical Application. hlm:1-17.

Gultom, N.M. 2010. Biologi dan kelimpahan populasi tungau merah Tetranychus kanzawai (Acari: Tetranychidae) pada dua kultivar jarak pagar (Jatropa curcas) [Tesis]. Bogor (ID): Institut Pertanian Bogor.

Indiati, S.W. 2012. Ketahanan varietas/klon ubi kayu genjah terhadap tungau merah. Penelitian Pertanian Tanaman Pangan. 31(1):53-59.

Khoiri, M.R. 2005. Tetranychus kanzawai (Acari: Tetranychidae) biologi dan populasinya pada ubi kayu di Bogor [Skripsi]. Bogor (ID): Institut Pertanian Bogor.

Nukenine, E.N., A.G.O. Dixon, A.T. Hassan, J.A.N. Asiwe. 1999. Evaluation of cassava cultivar for canopy retention and it's relationship with field resistence to green spider mite. African Crop Sci J. 7(1):47-45.

Prihandana, R, K. Noerwijan, P.G. Adinura, D. Setyaningsih, S. Setiadi dan R. Hendroko. 2007. Bioetanol Ubi kayu: Bahan Bakar Masa Depan. Jakarta (ID): PT Agromedia Pustaka. 
Skorupska, A. 2004. Resistance of apple cultivars to twospotted spider mite, Tetranychus urticae Koch (Acarina: Tetranychidae) part 1. Bionomi of twospotted spider mite on selected cultivars of apple trees. J Plant Prot Res. 44(1):75-80.

Sundari, T. 2010. Pengenalan Varietas Unggul dan Teknik BudidayaUbikayu (Materi Pelatihan Agribisnis bagi $K M P H)$ Malang (ID): Balai Penelitian Kacang- kacangan dan Umbi-umbian.

Takafuji, A. dan T. Ishii. 1989. Inheritance of sex ratio in the Kanzawa spider mite Tetranychus kanzawai Kishida (Acari: Tetranychidae). Res Pop Ecol. 31(1):123-128.

Zhang, Z.Q. 2003. Mites of Greenhouse, Identification, Biology, an Control. Cambridge (GB): CABI Publishing. 